\title{
PENTINGNYA SARANA PENDIDIKAN DALAM MENUNJANG KUALITAS PENDIDIKAN DI SEKOLAH
}

\author{
Oleh : \\ Ni Wayan Sri Yustikia \\ Pengawas Madya Tingkat Tk Di Kementerian Agama Kabupaten Badung
}

\begin{abstract}
Indonesian constitution mandate regarding the effort to improve the nation's education level is not an easy thing to do and not to be regarded merely as a political product. The mandate is a prerequisite of the glory of The Indonesian republic, and therefore no bargaining should be made over it. The National education Act as the implementation of the mandate in the Indonesian Constitution, has already followed by the increase in the National Education Budget into 20\% of the National Income and Expense Budget. Such a fantastic move and this writing will elaborate the use of such fund in real life to accommodate the needs of the students.

The vital means of education, starting from the classroom, teaching and learning aids, learning medias, books, journal, and encyclopedia as the source of learning should be improved. Therefore the implementation of the constitution should be based on the empirical needs of education. Brilliant students, the improvement education of Indonesia should be the goal of a great nation such as Indonesia.
\end{abstract}

Key words : Education means, quality, school

\begin{abstract}
ABSTRAK
Mandat konstitusi Indonesia mengenai upaya peningkatan tingkat pendidikan bangsa bukanlah hal yang mudah dilakukan dan tidak dianggap hanya sebagai produk politik. Mandat adalah prasyarat kemuliaan dari Republik Indonesia, dan dengan demikian tidak ada tawar menawar yang harus dilakukan di atasnya. UU Pendidikan Nasional sebagai Implementasi dari mandat pada konstitusi Indonesia, telah diikuti oleh peningkatan anggaran pendidikan nasional menjadi $20 \%$ dari APBN. Suatu langkah yang fantastis dan tulisan ini akan menguraikan penggunaan dana tersebut dalam kehidupan nyata untuk mengakomodasi kebutuhan siswa.

Sarana vital pendidikan mulai dari keas, sarana belajar, media pembelajaran, buku, jurnal, dan ensiklopedia sebagai sumber pembelajaran harus ditingkatkan. Oleh karenanya implementasi dari konstitusi harus berdasarkan pada kebutuhan empiris pendidikan siswa yang brilian, peningkatan kualitas pendidikan di Indonesia harus menjadi tujuan dari negara hebat seperti Indonesia.
\end{abstract}

\section{A Latar Belakang}

Dalam hal penguasaan dan pengembangan teknologi, penggunaan sarana pendidikan yang dapat dikatakan sebagai teknologi pendidikan dalam proses belajar teknologi dapat memfasilitasi pebelajar untuk berinteraksi langsung dengan dunia teknologi yang memudahkan pemahaman mereka dan menghindari verbalisme.

Kebutuhan sarana pendidikan tidaklah cukup hanya yang berkaitan langsung dengan kegiatan belajar dan pembelajaran di kelas saja seperti buku sumber, peralatan, perabot, dan media pendidikan saja.Pendidikan di sekolah juga membutuhkan sarana pendidikan yang secara tidak langsung mendukung terlaksananya kegiatan belajar dan pembelajaran di kelas seperti kebutuhan lahan, bangunan atau ruang, serta peralatan dan perabot untuk terselenggaranya manajemen sekolah secara bermutu.Kebutuhan sarana pendidikan seperti ini secara minimal tentu disesuaikan dengan tingkat kebutuhan, jenis, dan fungsinya (Depdiknas, 2003). Kebutuhan sarana pendukung ini diperlukan untuk memberikan 
pelayanan yang optimal bagi berlangsungnya proses pendidikan yang bermutu.

Tahun - tahun belakangan ini pemerintah mulai menyadari akan adanya standar pendidikan yang jelas yang dapat diacu oleh setiap penyelenggara pendidikan, baik di tingkat nasional maupun daerah. hal ini terbukti dengan dimasukkannya materi Standar Nasional Pendidikan pada bab IX Undang - Undang No. 20 tahun 2003 tentang Sistem Pendidikan Nasional. Sebagai penjabarannya lahirlah Peraturan Pemerintah No. 19 Tahun 2005, tentang Standar Nasional Pendidikan.Standar Nasional Pendidikan merupakan kriteria minimal tentang sistem pendidikan di seluruh wilayah hukum Negara Kesatuan Republik Indonesia. Lingkup Standar Nasional Pendidikan ini meliputi : standar isi, standar proses, standar kompetensi lulusan, standar pendidik dan tenaga kependidikan, standar sarana dan prasarana, standar pengelolaan, standar pembiayaan, dan standar penilaian seperti yang telah disebutkan di atas.

Berkaitan dengan standar sarana pendidikan dinyatakan bahwa setiap satuan pendidikan wajib memiliki sarana yang meliputi perabot, peralatan pendidikan, media pendidikan, buku dan sumber belajar lainnya, bahan habis pakai, serta perlengkapan lain yang diperlukan untuk menunjang proses pembelajaran yang teratur dan berkelanjutan, seperti keperluan gedung dan lahan (Depdiknas, 2003). Peraturan pemerintah ini belum menjabarkan lebih jauh apa jenis dan spesifikasi sarana pendidikan yang esensial dan seberapa besar kebutuhan minimal oleh masing - masing sekolah pada setiap jenjang dan jenis program pendidikan. Demikian pula rincian mengenai kebutuhan sarana esensial dan minimal untuk setiap jenis kegiatan manajemen pendidikan, proses belajar mengajar, dan proses evaluasi program.

Keterbatasan anggaran yang dimiliki pemerintah pusat maupun daerah mengisyaratkan pemerintah daerah agar memiliki data base yang jelas tentang jenis dan tingkat kebutuhan minimal sarana pendidikan pada setiap jenjang pendidikan, bahkan untuk setiap jenis kegiatan penyelenggaraan pendidikan. Kemampuan masyarakat dalam menyediakan sarana pendidikan di daerahnya sesuai dengan kondisi sosial ekonominya juga perlu diidentifikasi.Selanjutnya perlu dikaji secara ilmiah pengembangan sarana pendidikan bagi sekolah - sekolah di setiap jenjang untuk meningkatkan daya saing pendidikan di tingkat lokal, nasional, dan internasional. Hasil kajian ilmiah ini akan sangat bermanfaat bagi pemerintah pusat dan pemerintah daerah dalam pengambilan kebijakan yang tepat dalam perencanaan, implementasi, dan monitoring program program pendidikan, khususnya dalam penyediaan sarana prasarana. Kajian ilmiah ini juga sangat bermanfaat dalam memenuhi prinsip keadilan, transparansi, efisiensi dan akuntabilitas pengelolaan dana pendidikan khususnya dalam kaitannya dengan pengadaan sarana pendidkan.

Tersedianya sarana pendidikan sekolah yang memadai juga diduga memiliki korelasi yang kuat dengan peningkatan kualitas proses dan hasil belajar program pendidikan di sekolah (Depdiknas, 2005a, 2005b). Dalam hal ini, sarana pendidikan, terutama yang menyangkut fasilitas pembelajaran, sumber belajar, dan media pembelajaran (Depdiknas, 2005b) diduga mempunyai pengaruh yang kuat terhadap peningkatan hasil belajar yang diharapkan. Sarana pembelajaran yang tepat di samping dapat menjadi media pendidikan (belajar) yang akan membantu mempermudah proses berpikir anak melalui konkritisasi objek objek abstrak, juga dapat menjadi objek belajar itu sendiri yang akan membantu peserta didik memahami fenomena fenomena alam, sosial, budaya, dan teknologi secara langsung. Dengan kata lain, memanfaatkan sarana belajar dan pembelajaran yang memadai memungkinkan peserta didik tidak saja akan belajar how to know tetapi juga belajar how to do, how to be, dan how to live together. Pelibatan prosesbelajar secara utuh, komprehensif, dan powerfull seperti ini jelas membantu peserta didik mewujudkan potensi belajarnya secara 
optimal (Santiyasa, 1999; Sukadi, 2004; Wahab, 2002).

\section{PEMBAHASAN}

\section{A Penetapan Kebutuhan Esensial Sarana Pendidikan}

Pembangunan Nasional bidang pendidikan dilaksanakan berdasarkan Pancasila dan Undang - Undang Dasar 1945.Tujuannya adalah berkembangnya potensi peserta didik agar menjadi manusia yang beriman dan bertakwa kepada Tuhan Yang Maha Esa, berakhlak mulia, sehat, cakap, kreatif, dan bertanggung jawab (UU RI No. 20 Tahun 2003).Dalam konteks ini pemerintah, telah membangun dan mengembangkan satu sistem pendidikan nasional yang di dalamnya termasuk subsistem pendidikan dasar dan menengah.Pendidikan dasar dan menengah diarahkan untuk meletakkan dasar - dasar, nilai - nilai pengetahuan, keterampilan, dan sikap yang bermanfaat untuk menghadapi hidup pada masa mendatang (Propenas 20002004).

Telah disadari bahwa tingkat keberhasilan berbagai jenis dan jenjang pendidikan dipengaruhi oleh banyak komponen, di antaranya dipengaruhi oleh kualitas dan kuantitas komponen : 1) program pendidikan (termasuk di dalamnya kurikulum, silabus, bahan ajar, metode/media, alat peraga, dan alokasi waktu), 2) sarana dan prasarana (gedung, alat, perabot, bahan, buku, dll), 3) pendidik (guru, instruktur, pamong belajar, fasilitator, konselor, tutor, dan sebutan lain yang sesuai dengan kekhususannya) dan tenaga kependidikan yang mendukungnya, 4) pastisipasi masyarakat/stakeholders, dan 5) daya dukung lingkungan internal dan eksternal (Dirjen Dikdasmen, 2003).

Sarana pendidikan merupakan komponen integral dari penyelenggaraan pendidikan pada semua jenis dan jenjang pendidikan.Tanpa ditunjang oleh sarana yang memadai sulit diharapkan penyelenggaraan pendidikan yang menghasilkan sumber daya manusia yang berkualitas dan berdaya saing tingggi. Sumber daya manusia yang berkualitas itu, antara lain dicirikan oleh penguasaan iptek yang tinggi, penguasaan keterampilan di bidangnnya , memiliki komitmen, nilai - nilai dan sikap yang positif terhadap kemajuan, bertanggung jawab atas seluruh bidang kerja yang digelutinya , mempunyai kecakapan sosial yang memadai , dan memiliki keperibadian serta keimanan yang mantap ( Sukadi,2005).

Salah satu faktor yang ditengarai sebagai penyebab rendahnya mutu penyelenggaraan pendidikan di Indonesia selama ini adalah kurangannya sarana prasarana pendidikan yang dapat disedikan oleh pemerintah, pemerintah daerah, dan masyarakat. Menyadari hal ini, Departemen Pendidikan Nasional dalam Rencana Srategi tahun 205-2009 telah mencanangkan program penyediaan sarana pendidikan yakni sarana belajar untuk meningkatkan mutu dan relevansi pendidikan mulai dari pengabdian dasar sampai pendidikan tinggi.

Sarana pendidikan menurut PP No.19 pendidikan, media pendidikan, buku dan serta sumber belajar lainnya, bahan habis pakai serta perlengkapan lainnya yang diperlukan untuk menunjang proses pembelajaran yang teratur dan berkelanjutan. Sarana pendidikan menurut pengertian ini tidak secara tegas dan jelas memasukkan unsur kebutuhan lahan dan jelas bangunan menjadi bagian dari sarana pendidikan. Depdiknas (2003) , selanjutnya , dalam pedoman Analisis Kebutuhan Sarana Pendidikan Sekolah Menengah Kejuruan telah menetapkan bagian dari kebutuhan sarana pendidikan itu meliputi kebutuhan ruang bangunan, peralatan, perabot, dan kebutuhan lahan.

Walau demikian, kebutuhan sarana pendidikan untuk tiap, kebutuhan sarana pendidikan untuk tiap jenjang dan jenis pendidikan tidaklah harus sama pemenuhan unsusr - unsur sarana pendidikannya. pada tingkat pendidikan sekolah dasar peningkatkan saran belajar, misalnya , akan meliputi : perpustakaan, media pengajaran, alat peraga pendidikan, buku pelajaran, alat peraga pendidikan, buku pelajaran, buku bacaan lain yang relevan dengan mengacu 
pada standar sarana prasarana . Untuk sekolah dasar (SD) kebutuhan alat peraga pendidikan antara lain untuk semua runtun mata pelajaran (Agama , PPKn,IPA,IPS, matematika,Bahasa Indonesia, olahraga, Bahasa bali,kesenian,keterampilandan muatan lokal ). Sementara itu, untuk SMP dan SMA dilakukan penyediaan laboratorium dan media IPA serta laboratorium Bahasa dan komputer (Depdiknas, 2005).

Bertolak dari UU RI.No. 20 Tahun 2003 ini, pemerintah daerah berkewajiban untuk memenuhi sarana pendidikan untuk semua satuan dan jenjang pendidikan di wilayahnya yang menjadi tanggung jawab daerah.pemerintah perlu mengidentifikasi bagaimana kualitas dan kuantitas sarana prasarana pendidikan yang ada saat ini di setiap jenjang pendidikan ? Apakah keberadaan sarana dan prasarana ini telah memenuhi standar yang dipersyaratkan ?Sejauh mana pemanfaatan sarana-prasarana yang sudah ada dan kontribusinya terhadap peningkatan mutu dan relevansi pendidikan.Untuk ini pemerintah daerah perlu mengidentifikasi kebutuhan sarana yang paling esensial bagi terselenggaranya pendidikan yang optimal pada setiap jenis dan jenjang pendidikan, dan seberapa besar kemampuan masyarakat dalam menyediakan sarana prasarana yang dipelukan.

\section{B Standar Minimal Sarana Pendidikan}

Dalam PP No. 19 Tahun 2005 dijelaskan bahwa Standar Nasional Pendidikan meliputi : (1) Standar Isi, (2) Standar Proses, (3) Standar Kompetensi Lulusan, (4) Standar Pendidik dan Tenaga Kependidikan, (5) Standar Sarana dan Prasarana, (6) Standar Pengelolaan, (7) Standar Pembiayaan, (8) Standar Penilaian Pendidikan. Standar Nasional pendidikan ini berfungsi sebagai dasar dalam perencanaan, pelaksanaan, dan pengawasan pendidikan dalam rangka mewujudkan pendidik nasional yang bermutu.Tujuan dari standar nasional pendidikan ini adalah mencerdaskan kehidupan bangsa dan membentuk watak serta peradaban bangsa yang bermartabat.
Dalam bab VII, PP No. 19 Tahun 2003, secara khusus ditegaskan mengenai standar sarana dan prasarana. Dalam pasal 12 bab ini dinyatakan bahwa sarana yang meliputi perabot, peralatan pendidikan, media pendidikan, buku dan sumber belajar lainnya, bahan habis pakai, serta perlengkapan lain yang diperlukan untuk menunjang proses pembelajaran yang teratur dan berkelanjutan.

Selanjutnya pada pasal 43 diatur sebagai berikut : Standar keragaman jenis peralatan laboratorium ilmu pengetahuan alam (IPA), laboratorium Bahasa, laboratorium komputer, dan peralatan pembelajaran lain pada satuan pendidikan dinyatakan dalam daftar yang berisi jenis minimal peralatan yang harus tersedia (ayat 1). Standar jumlah peralatan dinyatakan dalam rasio minimal jumlah peralatan per peserta didik (ayat 2).Standar buku dinyatakan dalam jumlah judul dan jenis buku di perpustakaan satuan pendidikan (ayat 3).Standar jumlah buku teks pelajaran di perpustakaan dinyatakan dalam rasio minimal jumlah buku teks pelajaran untuk masing masing mata pelajaran di perpustakaan satuan pendidikan untuk setiap peserta didik (ayat 4).Standar sumber belajar lainnya untuk setiap satuan pendidikan dinyatakan dalam ratio jumlah sumber belajar terhadap peserta didik sesuai dengan jenis sumber belajar dan karakteristik satuan pendidikan (ayat 6).Setiap satuan pendidikan, pemerintah daerah, maupun masyarakat dalam menyediakan sarana pendidikan harus mengacu pada ketentuan yang diatur dalam PP ini.

Ketentuan dalam peraturan pemerintah di atas belum menetapkan secara tegas besaran - besaran rasio minimal kebutuhan masing - masing unsur sarana pendidikan yang telah dijelaskan di atas.Karena itulah, perlu dikembangkan asumsi - asumsi, langkah - langkah, dan pendekatan analisis sehingga kebutuhan minimal sarana pendidikan tiap - tiap jenjang dan jenis pendidikan dapat ditentukan.hal ini tentu perlu juga disesuaikan dengan fungsi atau kegunaan serta daya dukung masing masing jenis sarana pendidikan. Untuk 
kepentingan penentuan ini, pedoman analisis kebutuhan sarana pendidikan yang telah dikembangkan oleh Depdiknas (2003) dapat digunakan sebagai pedoman terutama yang menyangkut kebutuhan ruang/bangunan, peralatan, perabot, serta kebutuhan lahan.

Sesuai dengan pedoman ini, aktivitas pembelajaran sebagai aktivitas pokok pendidikan yang bertujuan memberdayakan dan mengembangkan kompetensi peserta didik haruslah menjadi dasar utama dalam penentuan kebutuhan sarana pendidikan di sekolah. Aktivitas pembelajaran ini secara empiris memiliki implikasi utama dalam menentukan kebutuhan sarana pendidikan baik secara langsung maupun tidak langsung agar pembelajaran itu sendiri berlangsung secara memadai, efektif, dan efisien dalam menghasilkan lulusan yang sesuai dengan tuntutan kebutuhan masyarakat, tuntutan perkembangan ilmu pengetahuan dan teknologi, serta tuntutan dunia kerja. Dengan begitu aktivitas pembelajaran dapat dianalisis implikasinya terhadap kebutuhan ruang dan dengan begitu memerlukan jumlah lahan tertentu untuk ruang bangunan, terhadap kebutuhan peralatan, perabot, sumber belajar, media pendidikan/pembelajaran, alat tulis kantor dan bahan habis, serta sarana pendukung lainnya. dari analisis implikasi seperti itu akan dihasilkan kebutuhan sarana pendidikan dalam jenis dan jumlahnya sesuai dengan tuntutan pengembangan kompetensi serta sesuai pula dengan fungsi atau kegunaan masing - masing jenis sarana dalam menunjang keberhasilan aktivitas pembelajaran berbasis kompetensi (Depdiknas, 2003).

\section{Kebutuhan Ruang/Bangunan}

Pada dasarnya penetapan kebutuhan ruang untuk program pendidikan dilakukan dengan pendekatan empirik dan studi referensi berdasarkan pengalaman masa lalu untuk melihat kebutuhan masa ini dan masa depan bagi peserta didik (Depdiknas, 2003). Karena itu perencanaan kebutuhan ruang disusun berdasarkan fungsi dan kegunaan ruang itu dalam proses pendidikan dan pembelajaran. Fungsi dan kegunaan ruang umumnya berkaitan dengan pihak - pihak yang menggunakan dan jenis kegitan dari pihak - pihak pemakai. Dalam hal ini fungsi ruang umumnya diklasifikasi menjadi tiga bagian, yaitu : kelompok ruang pembelajarn, perkantoran, dan ruang penunjang pembelajaran. Dari segi pemakainya, kebutuhan ruang/bangunan dapat difungsikan untuk ruang kepala sekolah, ruang guru, ruang pegawai tata usaha, ruang aktivitas pembelajaran siswa, ruang tamu dan pihak luar (termasuk komite sekolah).Dengan kriteria fungsi dan pemakainya maka dapatlah ditentukan kebutuhan minimal ruang/bangunan di sekolah yang meliputi jenis, jumlah, fungsi pokok, dan luas ruang. Penentuan jenis, jumlah, fungsi pokok, dan luas ruang ini pula akan disesuaikan dengan karakteristik kebutuhan pada tiap - tiap jenjang dan jenis sekolah, terutama yang berkaitan dengan kebutuhan ruang untuk fungsi - fungsi pembelajaran (Depdiknas, 2003).

\section{Kebutuhan Lahan}

Kebutuhan lahan untuk tiap - tiap jenjang dan jenis sekolah umumnya ditentukan atas kebutuhan minimal luas bangunan sesuai dengan fungsi dan kegunaannya ditambah dengan keperluan infrastruktur penunjang yang pokok diperlukan yang menurut pedoman standar minimal dari Depdiknas (2003) minimal mencapai $20 \%$ dari luas lahan untuk keperluan bangunan. Karena itu perlu diidentifikasi jenis - jenis dan luas bangunan yang esensial dan minimal yang diperlukan untuk tiap - tiap sekolah dan selanjutnya dapat ditambahkan minimal $20 \%$.

\section{Kebutuhan Peralatan Pendidikan}

Kebutuhan peralatan pendidikan disesuaikan dengan kebutuhan empiris di sekolah yang disesuaikan dengan tuntutan aktivitas utama pembelajaran berdasarkan kurikulum yang berlaku serta kebutuhan peralatan penunjang lainnya dalam 
keseluruhan aktivitas pendidikan di sekolah. Berdasarkan kebutuhan seperti itu maka kebutuhan jenis peralatan pendidikan yang diperlukan di sekolah dapat dikelompokkan, antara lain : peralatan/media pembelajaran, peralatan praktik laboratorium, peralatan administrasi perkantoran, dan peralatan penunjang terutama yang terkait dengan peralatan pemeliharaan dan perawatan (Depdiknas, 2003).

Untuk keperluan peralatan/media pembelajaran dan peralatan praktik laboratorium penentuan kebutuhan minimal jenis peralatan akan ditentukan oleh jenis aktivitas belajar yang diharapkan mencapai kompetensi tertentu sesuai dengan tuntutan kurikulum. Sedangkan jumlah kebutuhan peralatan ditentukan, antara lain oleh sifat pembelajaran dapat dilakukan menurut sistem klasikal, jumlah rombongan belajar, kelompok besar atau kecil, atau belajar secara individual. Umumnya penggunaan media pembelajaran dalam pemahaman teori dapat dilakukan secara klasikal atau penggunaan kelompok besar, sedangkan belajar yang mengutamakan kemampuan praktikum di laboratorium atau bengkel kerja peralatan yang dibutuhkan umumnya bersifat individual atau penggunaan kelompok kecil.

\section{Kebutuhan Perabot Pendidikan}

Perabot, oleh Depdiknas 92003) disamakan dengan mebeler yang terdiri dari mebeler yang dapat dipindahkan/disusun sesuai kebutuhan suatu waktu, seperti meja dan kursi tamu; dan mebeler yang tetap/tidak dipindahkan dalam jangka waktu yang lama, seperti lemari besi tempat penyimpanan uang.Kebutuhan perabot di sekolah ditentukan oleh jenis kegiatan yang dilakukan di sekolah, kelompok pemakai, ruang penempatan perabor, serta jumlah pemakainya.Karena itu, komponen komponen ini perlu dianalisis terlebih dahulu sebelum menentukan jenis dan jumlah perabot yang dibutuhkan di sekolah.

Yang dimaksud dengan kegitan di sekolah adalah segala sesuatu yang dilakukan untuk mencapai tujuan pendidikan di sekolah yang meliputi kegiatan manajemen dan administrasi sekolah, kegiatan kurikulum dan pembelajaran, kegiatan supervise pendidikan, kegiatan pembinaan kesiswaan, bimbingan siswa, hubungan dengan masyarakat, kegiatan evaluasi atau asesmen, dan kegiatan penunjang lainnya. Semua jenis kegiatan ini tentu memerlukan alat bantu, seperti alat tulis, alat peraga, alat praktik, sumber belajar, alat dokumentasi, alat - alat pemeliharaan dan kebersihan, dan lain - lain. Semua jenis peralatan ini tentu memerlukan wadah atau tempat. Perabot sekolah dapat menjadi wadah atau tempat penyimpanan bagi alat - alat bantu pendidikan tersebut. Perabot seperti ini, misalnya : lemari, filling cabinet, rak buku, meja kerja, rak penyimpanan alat - alat, dan sebagainya.

Kelompok pemakai perabot di sekolah dalam hal ini adalah kepala sekolah, para guru, siswa, pegawai tata usaha, pengurus komite, dan tamu/orang luar.Masing - masing pemakai ini tentu memerlukan perabot sendiri - sendiri.Kepala sekolah, pengurus komite, dan guru, misalnya, membutuhkan masing masing kursi dan meja kerja, lemari atau rak penyimpanan peralatan, dan sebagainya. Siswa, misalnya, membutuhkan kursi dan meja belajar, papan tulis, meja praktik, rak penyimpanan tas dan alat tulis lainnya, dan sebagainya.

Kebutuhan perabot sekolah juga ditentukan jumlah pemakainya.Kebutuhan yang paling besar umumnya adalah kebutuhan perabot untuk guru dan siswa yang harus dipenuhi bersifat individual. Kebutuhan pemakai yang lain juga esensial, dank arena itu harus disesuaikan dengan tingkat kebutuhan dan jumlah pemakainya.

\section{Kebutuhan Sumber Belajar}

Sarana sumber belajar di sekolah adalah segala sesuatu yang dapat digunakan sebagai sarana untuk memperoleh informasi belajar, antara lain berupa buku paket, buku penunjang, LKS, jurnal atau majalah, majalah mingguan, surat kabar harian, komputer dengan media internet, televisi pendidikan, radio, laporan penelitian, dan sejenisnya.

Kebutuhan masing - masing jenis sumber belajar tersebut akan sangat 
tergantung pada tingkat urgensi sumber belajar tersebut, fungsi dan kegunaan sumber belajar tersebut dalam menunjang pencapaian tujuan pengembangan kompetensi sesuai dengan tuntutan standar kurikulum, pemakainya, dan jumlah pemakai. Untuk buku paket/ajar pegangan guru dan siswa, LKS, dan buku - buku penunjang utama umumnya adalah sumber belajar yang paling vital dibutuhkan baik oleh guru maupun siswa. Karena itu, kebutuhannya haruslah dipenuhi secara individual dan akan sangat tergantung pada jumlah guru dan siswa.

Untuk kebutuhan buku - buku pendukung baik yang bersifat ilmiah, popular, maupun buku fiksi serta jurnal urgensinya jelas tidak seutama buku- buku ajar, LKS, dan buku - buku penunjang buku ajar utama. Karena itu, kebutuhannya tentu akan sangat tergantung pada urgensi sumber - sumber tersebut baik bagi guru maupun siswa serta berdasarkan data penggunaan sebelumnya. Buku - buku pendukung yang keberadaannya sangat dibutuhkan dan sering digunakan kebutuhannya tentu lebih banyak dari pada buku - buku pendukung yang kurang kebutuhannya dan jarang digunakan sebelumnya.Begitu pula dengan sumber sumber belajar yang berupa laporan penelitian.

Sumber belajar yang berupa surat kabar dan majalah serta kliping umumnya sudah menjadi kebutuhan sehari-hari. Tetapi, karena kebutuhannya bagi proses pembelajaran sering tidak bersifat langsung, maka urgensinya juga tidaklah sepenting buku ajar atau buku paket. Bagi kepentingan sekolah, memiliki satu jenis harian dan majalah yang berskala daerah, satu berskala nasional, dan satu berskala internasional yang dapat mendukung proses pembelajaran bagi pencapaian pengembangan kompetensi siswa sesuai dengan tuntutan kurikulum tentu mutlak kepentingannya. Untuk jumlahnya tentu dapat disesuaikan dengan kelompok pengguna : kepala sekolah, kelompok guru, pegawai, dan kelompok siswa.

Penggunaan komputer plus program internet sebagai sumber belajar dewasa ini sudah menjadi kebutuhan utama.Bahkan mata pelajaran teknologi informasi dan komunikasi telah dimasukkan ke dalam kurikulum sekolah dari jenjang sekolah dasar hingga tingkat sekolah menengah atas.Karena itu kebutuhan komputer dan internet sebagai sumber belajar sudah tidak dapat ditawartawar lagi.Kebutuhan komputer dan internet sebagai sumber belajar sangat dibutuhkan oleh guru dan siswa. Kebutuhannya tentu akan ditentukan oleh tingkat urgensi dan fungsi serta kegunaannya bagi kelompok pemakai, jumlah pemakai, serta sistem pengelolaannya yang efektif dan efisien. Karena pengguna sumber belajar komputer dengan internetnya dapat digunakan dengan model klasikal atau rombongan belajar maka kebutuhan jumlahnya dapat memperhatikan penggunaan optimal bagi tiap - tiap kelas/rombongan belajar disesuaikan dengan jatah waktu penggunaan bagi tiap - tiap kelas/rombongan belajar serta jumlah siswa dalam satu kelas/rombongan belajar.

\section{Peran Pemerintah Daerah dan Masyarakat dalam Penyelenggaraan Pendidikan}

Sejak diundangkannya UU No. 22 tahun 1999 tentang Pemerintahan Daerah, daerah diberi kewenangan untuk mengatur dan mengurus kepentingan masyarakat setempat menurut prakarsa sendiri berdasarkan aspirasi masyarakat sesuai dengan peraturan perundang-undangan. Kewenangan diberikan kepada daerah dalam wujud otonom luas, nyata, dan bertanggung jawab.

Kewenangan daerah kabupaten dan kota, sebagaimana dirumuskan dalam pasal 11, mencakup semua bidang pemerintahan, yakni pekerjaan umum, kesehatan, pendidikan dan kebudayaan, pertanian, perhubungan, industri dan perdagangan, penanaman modal, lingkungan hidup, pertahanan, koperasi serta tenaga kerja. Jelaslah bahwa kebijakan pendidikan berada di bawah kewenangan daerah kabupaten dan kota.

Konsekwensidari keluarnya undangundang pemerintahan daerah tersebut adalah terjadinya perubahan dalam berbagai bidang 
penyelenggaraan kehidupan pemerintahan, salah satunya adalah penyelenggaraan pendidikan. Jika sebelumnya manajemen pendidikan merupakan wewenang pusat, dengan berlakunya undang - undang tersebut manajemen pendidikan menjadi wewenang pemerintah kabupaten dan kota.

Selain dalam undang - undang pemerintah daerah, kewenangan dan tanggung jawab pemerintah daerah dalam penyelenggaraan dan pembiayaan pendidikan juga diatur dalam UU RI No. 20 tahun 2003, tentang Sistem Pendidikan Nasional.Sesuai dengan UU RI No. 20 Tahun 2003 tanggung jawab pemerintah daerah dalam penyelenggaraan pendidikan di daerah bersangkutan sangat esensial.Sebagaimana ditegaskan dalam pasal 10 undang - undang ini, bahwa pemerintah dan pemerintah daerah berhak mengarahkan, membimbing, membantu, dan mengawasi penyelenggaraan pendidikan sesuai dengan peraturan dan perundang-undangan yang

berlaku.Pemerintah daerah bersama-sama pemerintah wajib memberikan layanan dan kemudahan, serta menjamin terselenggaranya pendidikan yang bermutu tinggi bagi setiap warga negara tanpa diskriminasi. Pemerintah daerah juga berkewajiban menyediakan dana guna terselenggaranya pendidikan bagi setiap warga negara yang berusia tujuh sampai lima belas tahun. Secara lebih tegas mengenai pembiayaan pendidikan dinyatakan bahwa pemerintah daerah harus mengalokasikan dana pendidikan sebesar 20\% dari Anggaran Pendapatan dan Belanja Daerah (APBD).

Dari paparan di atas jelaslah pemerintah daerah memiliki tanggung jawab yang besar dalam memenuhi kebutuhan penyelenggaraan pendidikan yang bermutu tinggi, termasuk dalam menyediakan sarana dan prasarana yang memadai.Pemenuhan kebutuhan ini hendaknya dilakukan melalui kajian yang mendalam terhadap sarana yang paling esensial, yang minimal harus ada, sesuai dengan kebutuhan, tepat guna, dan tepat sasaran.Selanjutnya pemantauan terhadap pemanfaatan sarana ini harus dilakukan secara kontinu untuk menjamin bahwa sarana ini benar - benar digunakan untuk kepentingan peningkatan mutu sekolah.Perlu pula dikembangkan sarana pendidikan yang lebih luas dan kompleks bagi sekolah - sekolah tertentu yang relatif sudah maju untuk meningkatkan daya saingnya di tingkat lokal, nasional dan internasional.

Bantuan pemerintah, baik pemerintah pusat maupun pemerintah daerah (propinsi dan kabupaten/kota), dalam pengadaan sarana pendidikan dapat dilakukan melalui hibah kompetisi dan school grant serta bantuan subsidi imbal swadaya (Depdiknas, 2006) terutama dialokasikan pada kebutuhan sarana ruang/bangunan dan pengadaan peralatan pendidikan utama untuk kepentingan proses pembelajaran dan kegiatan praktikum baik di laboratorium maupun bengkel kerja, serta untuk pengadaan sumber - sumber belajar. Pengalokasian bantuan pemerintah seperti ini dinilai amat penting agar pengadaan sarana pendidikan utama seperti ini tetap dapat terkontrol penetapan standar pemenuhan kebutuhannya yang esensial dan minimal tanpa harus mengabaikan adanya peran partisipasi orang tua (komite sekolah) dan masyarakat pada umumnya.

Di era otonomi daerah seperti sekarang, peranan masyarakat secara langsung dalam pelaksanaan program pendidikan di sekolah dalam rangka meningkatkan mutu pendidikan merupakan kondisi yang mutlak diperlukan.Dengan keterbatasan kemampuan pemerintah dalam menyediakan fasilitas dan sarana pendidikan, maka peranan dan partisipasi masyarakat untuk menunjang keberhasilan program pendidikan di sekolah mendapat tempat yang senbtral dan strategis pula. Peranan dan partisipasi masyarakat dalam pelaksanaan program pendidikan, khususnya dalam pengadaan kebutuhan sarana pendidikan, tentu dapat dialokasikan pada semua jenis kebutuhan sarana pendidikan, walau dalam sehari-harinya lebih terfokus pada operasionalisasi pelaksanaan proses pendidikan di sekolah. Hal ini tentu akan sangat tergantung pada tingkat kemampuan sosial ekonomi masyarakat serta komitmen mereka dalam turut memajukan program pendidikan di daerahnya. Bagaimanapun 
peran dan partisipasi masyarakat dalam turut membantu pelaksanaan program pendidikan perlu dipelajari kondisinya agar dapat diambil kebijakan yang relevan sesuai dengan kondisi mereka di maisng - masing daerah.

\section{Kontribusi Sarana Pendidikan terhadap Kualitas Pendidikan}

Semangat otonomi daerah telah mengilhami munculnya pemikiran kea rah pengelolaan pendidikan yang memberi keleluasaan kepada sekolah untuk mengatur dan melaksanakan berbagai kebijakan secara luas.Pemikiran ini dalam perjalanannya disebut manajemen peningkatan mutu berbasis sekolah (MPMBS) (Mulyasa, 2002).Tujuan utama MPMBS adalah meningkatkan efisiensi, mutu, dan pemerataan pendidikan.Peningkatan efisiensi diperoleh melalui keleluasaan mengelola sumber daya yang ada, partisipasi masyarakat, dan penyederhanaan birokrasi. Peningkatan mutu diperoleh melalui partisipasi orang tua, kelenturan pengelolaan sekolah, peningkatan profesionalisme guru, adanya hadiah dan hukuman sebagai control, serta hal lain yang dapat menumbuhkembangkan suasana kondusif. Pemerataan pendidikan tampak dari tumbuhnya partisipasi masyarakat terutama yang mampu akan menjadi tanggung jawab negara.

Secara umum mutu adalah gambaran dan karakteristik menyeluruh dari barang atau jasa yang menunjukkan kemampuannya dalam memuaskan palanggan yang diharapkan atau tersirat. Dalam konteks pendidikan, pengertian mutu tercakup input, proses dan output pendidikan (Depdiknas, 2002:7). Input pendidikan adalah segala sesuatu yang harus tersedia untuk berlangsungnya proses pendidikan. Input pendidikan dapat berupa sumber daya dan perangkat lunak serta harapan - harapan sebagai pemandu berlangsungnya proses. Input sumber daya meliputi sumber daya manusia dan sumber daya selebihnya termasuk sarana prasarana pendidikan. Tinggi rendahnya mutu input dapat diukur dari tingkat kesiapan input.
Proses pendidikan merupakan berubahnya sesuatu menjadi sesutau yang lain. Sesuatu yang berpengaruh terhadap berlangsungnya proses disebut input, sedangkan hasil dari proses pendidikan disebut output pendidikan. Dalam pendidikan berskala mikro (sekolah) yang dimaksud dengan proses adalah pengambilan keputusan, pengelolaankelembagaan, pengelolaan program, proses belajar mengajar, dan proses monitoring dan EVALUASI. Proses pendidikan bermutu tinggi apabila pengkoordinasian dan penyerasian serta pemaduan input sekolah dilakukan secara harmonis, mampu mendorong motivasi dan minat belajar dan benar-benar mampu memberdayakan peserta didik.

Output pendidikan merupakan kinerja sekolah.Kinerja sekolah adalah presentaso sekolah.Perilaku sekolah dapat diukur kualitas kehidupan kerjanya, dan moral kerjanya.Ouput sekolah dikatakan berkuallitas tinggi apabila presentasi sekolah khususnya prestasi belajar siswa menunjukkan pencapaian tinggi apabila presentasi belajar siswa dapat berupa presentasi akademik dan non akademik. Prestasi akademik berupa nilai ulangan umum, ujian sekolah, ujian nasional kualitas karya ilmiah, dan lomba-lomba akademik; sedangkan prestasi non akademik berupa ketakwaan terhadap Tuhan Ynag Maha Esa, kejujuran, kesopanan, kecakapan olah raga, kemampuan berkesenian, keterampilan dan kegiatan-kegiatan ekstrakulikuler lainnya.

Seperti dijelaskan di atas, salah satu komponen input pendidikan adalah sarana pendidikan. Saran pendidikan adalah peralatan dan perlengkapan yang secara langsung dipergunakan dan smenunjang proses mengarah (Mulyasa, 2002). Sarana Pendidikan ini merupakan salah satu komponen pendidikan yang esensial. Tersedianya sarana pendidikan dalam jumlah yang memadai, dengan jenis yang beragam, dan kualuirras tinggi, dan dikelola secara baik dan tepat guna akan memberikan kontribusi yang optimal dan signifikan terhadap peningkatan kualitas proses dan output 
pendidikan dalam hal ini proses belajarmengajar dan presentasi belajar siswa.

Khususnya dalam kaitannya dengan proses belajar mmengajar, ketersediaan sarana pendidikan (khususnya material pembelajaran). yang memadai dan denga jenis yang beragam serta dengan jenis yang beragam serta dengan pengelolaan dan penggunaan yang tetapi akan meningkatkan kualitas yang tepat pembelajaran, karena akan memberikan kesempatan, karena akan memberikan kesempatan pada pebeljara untuk belajar melalui pengalaman (first hand experience) secara individu maupubn kelompok (Trowbrigde \& Bybee, 1990; Colletee \& Ciapetia, 1994; peter \& gega, 2002). Dalam kaitan ono, Klauser (1996) menyatakan bahwa untuk dapat belajar sains melalui inkuiri, siswa harus bersedia sarana/fasilitas belajar selengkap mungin, untuk memberikan kesempatan menggunakan sesring mungkin peralatan, buku sumber, dan sumber lainnya untuk melakukan eksperimen dan pengamatan lanagsung terhadap phenomena alam. Penganut paham kontruktivisme dengan pemebajaran kontekstual haruslah melibatkan aktivitas inkuiri dan penggunaan model dalam belajar. Aktivitas inkuiri dan pemodelan tentu tidak akan dapat dilakukan dengan baik tanya ada dapat alat bandtu dan media pembelajaranserta sumber-sumber belajar yang memadai. Itu artinya pembelajaran kontekstual yang akan memberikan pengalaman belajar yang lebih autentik dan powerful kepada siswa jika tidak disertai dukungan sarana Belajar dan pembelajaran yang memadai pula (Sukadi,2005).

Keterbatasan sarana pendidikan (peralatan Laboratorium IPA, IPS, Bahasa; buku selama ini cenderong mendorong proses pembelajaran tidak sesuai dengan hakikat subject matter dan kompetesni yang dituntut dalam kurikulum, sehingga menjadi kurang efektif dan membosankan serta mestinya dilakukan lewat pengalaman (learning by experience) dan belajar melalui partisipasi (learning by doing), terpaksa dengan ceramah. Keadaan ini terjadi pada yhampir semua disipling ilmu (IPA dan IPS).: Dari tingkat sekolah dasar sampai perguruan tinggi. Jadi di samping komponen lainnya, sarana pendidikan juga memberikan kontribusi yang singifikan pada kualitas proses dan hasol pendidikan.

Ada tiga jenis sarana pendidikan yang diduga secara langsung akan mempengaruhi kualitas proses pembelajaran dan pada gilirannya akan mempengaruhi prestasi pembelajaran dan pada gilirannya akan mempengaruhi prestasi belajar siswa. Ketiga jenis sarana pendidikan itu adalah dukungan penggunaan sumber-sumber belajar yang memadai, dukungan peralatan pendidikan dan pembelajaran termasuk peralatan laboratorium dan bengkel kerja, serta dukungan penggunaan media pembelajaran. Ketiga sarana pendidikan ini memang mempunyai hubungan langsung dengan kepentingan proses belajar dan pembelajaran yang kurang menggunakan dukungan ketiga jenis sarana ini akan mengakibatkan proses belajar siswa menjadi kurang bermakna dan powerful. Bersifat variabelsisme karena pembelajaran uang akan dilakukan melalui perusahaan hanya akan dilakukan penguasaan Bahasa verbal dan hanya melibatkan proses mengingat atau proses memoeri kerja belaka. Kurang bermakna, selanjutnya, karena belajar menjadi kurang autentik dan kurang berhubungan dengan pengembangan pengalaman belajar siswa yang nyata dan kurang berhubungan dengan lingkungan belajar yang lebih autentik. Belajar yang kurang bermakna dan kurang powerful akan bermuara pada prestasi belajar yang Rendah Baik Dari Domain kognisi, nilai-nilai dan sikap baik dan sikap, keterampilan penumbuhan rasa percaya diti (selfconfidence), pembinaan komitmen manapun pengembangan kompetensinya (NCSS, 200;Sukadi, 2005).

\section{SIMPULAN}

Berdasarkan uraian tersebut di atas maka dapatlah disimpulkan beberapa hal sebagai berikut.

1. Kebutuhan esensial sarrana pendidikan bagi jenjang pendidikan dapat 
dikategorikan menjadi kebutuhan perabot, kebutuhan peralatan/media pendidikan, kebutuhan sumber belajar, dan kebutuhan lahan. Seluruh penentuan kebutyuhan sarana pendidikan ini didasarkan pendekatan empiris dengan siswa, sifat, fungsi dan kegunaan sarana pendidikan, serta pemakai yang terlibat dalam prosesn pendidikan di sekolah.

2. Dalam asumsi-asumsi rasio jumlah siswa yang ditetapkan dengan pendekatan empiris dan studi perbandingan, pada jenjang pendidikan sekolah pemenuhan kebutuhan sarana pendidikan ternyata masih relative sangat rendah baik pada kebutuhan ruang/bangunan, perabot, perlaatan / media pendidikan, sumber belajar, manapun kebutuhan lahan. Karena itu masih dirasakan banyak kekurangan untuk memenuhi standar minimal kebutuhan sarana pendidikan. Untuk kekurangan tersebut pihak sekolah terutama mengharapkan bantuan pihak pemerintah baik daerah maupun kabupaten, propinsi, maupun pusat dalam alokasi APBD dan APBN terutama dalam memenuhi beberapa kekurangan sarana pendidikan yang menyangkut kebutuhan ruang bangunan, kebutuhan perabot utama, peralatan dan media pendidikan, serta sumber-sumber belajar penunjang untuk pengayaan.

3. Berdasarkan hasil studi korelasi ditemukan bahwa seluruh faktir sarana pendidikan mempunyai kontribusi yang signifikan dalam menjeaskan variabilitas prestasi belajar siswa baik prestasi dalam ujian nasional maupun ujian sekolah. Secara sendiri-sendiri keberadaan faktor perabot, peralatan, dan sumber belajar ternyata marupakan faktor yang paling signifikan.

\section{DAFTAR PUSTAKA}

Bafadal,I.(2004), Manajemen Perlengkapan Sekolah,Teori dan aplikasinya.jakarta :Bumi

Aksara .
COLLETTE, A.T \&Chiappetta, E.L.1994).Science Instuction in the middle and Secondary

school. Trhird Edition Sydney :

Maxwell Macillan.

Depdiknas.(2005a) praktek baik dalam penjaminan mutu pendidikan tinggi . Buku $V$ :

Depdiknas

prasarana dan sarana.Jakarta:

Depdiknas.(2005b). Draft 2 Rencana strategis Departemen Pendidikan Nasional tahun 2005-

2009.jakarta: Depdiknas

Depdinas.(2002). Manajemen peningkatkan mutu berbasis sekolah .Buku 1. Konsep dasar

.jakarta : Depdiknas

Depdiknas.(2003a).Kurikulum 2004.Standar Kompetensi Mata pelajrn sains.Sekolah

menengah Pertama dan Madrasah Tsanawiyah.Jakarta: Depdiknas.

..(2003b). Pedoman Analisis

Kebutuhan Sarana Pendidikan

Sekolah Menengh Kejuruan

(SMK):Program kehlian teknik elektronika

komunikasi.jakarta:Depdiknas

..(2006).Petunjuk pelaksanaaan

program subsidi imbal swadaya

pembangunan $R K B$

, perpustakaan dan laboratorium

IPA sekolah menengah pertama dengan

mekanisme partisipasi masyarakat . Jakarta : Depdiknas

Dirjen Dikdasmen.(2003).Kebijakan

Pengembangan Kurikulum. Manajemen

Suplai Dan 
Kebutuhan Guru Pendidikan Dasar Dan Menegah Pada Era Otonomi Dan Implementasinya Untuk Pengembangan LPTK Masa Depan. Makalah.Disampaikan Dalam Rapat Kerja Pimpinan LPTK Di Lingkungan Depdiknas.Di Jakarta Tanggal 10 - 12 Oktober 2003.

Kertiasa , Nyoman , dkk (1979) Petunjuk Pengolahan Laboratorium IPA SMA I Jakarta :

Departemen Pendidikan Dan Kebudayaan

Klausner ,R (Chairman) .(1996) . National Science Education Standards. Washington DC :

National Academy Press.

Mulyana, E. (2002). Manajemen Berbasis Sekolah. Konsep, Strategi dan Implementasi.

Bandung: Remaja Rosdakarya

Peters, J.M \& Gega, Peter C. (2002).Science in Elementary Education. $9^{\text {th }}$ Edition. Ohio:

Merril Prenice Hall.

Pusat Kurikulum, Balitbang Depdiknas. (2002). Kurikulum dan Hasil Belajar. Jakarta:

Depdiknas.

Anonim, (2005).Peraturan Pemerintah Republik Indonesia No 19 Tahun 2005. Tentang

Standar Nasional Pendidikan.

Santiyasa, I W. (1999). Pembelajaran Modul dengan Metode Demonstrasi dan Analogi

Sebagai Strategi Pengubah

Konsepsi Mahasiswa Jurusan

Pendidikan MIPA STKIP

Singaraja.Laporan Penelitian.

Singaraja: STKIP Singaraja.
Sevilla, C. G, dkk.(1983). Pengantar

Metodologi Penelitian.Terjemahan. Jakarta:

UI Press.

Sukadi.(2005). Penyusunan Standar Minimal Laboratorium Jurusan Pendidikan NonMIPA di Lingkungan IKIP Negeri Singaraja dalam Upaya Meningkatkan Standar Kompetensi Lulusan.Makalah.Disampaikan pada seminar P3AI menentukan standar minimal laboratorium, tgl 19 Nopember 2005.

Sukadi.(2004). Pembelajaran Mata Kuliah Belajar dan Pembelajaran Menggunakan Modeling Dosen Berbasis Konstruktibisme Pada Mahasiswa Semester III Jurusan PPKN IKIP Negeri Singaraja Tahun 2005/2006. Laporan Penelitian. Singaraja: IKIP Negeri Singaraja.

Tim Redaksi Fokusmedia. (2003). Himpunan Perundang-Undangan .UndangUndang RI No. 20 Tahun 2003 Tentang Sistem Pendidikan Nasional.Dilengkapi dengan Undang-Undang No. 2 Tahun 1989 Tentang Sistem Pendidikan Nasional. Bandung: Fokusmedia.

Trowbridge, L. W \& Bybee, R.W. (1990).Becoming A Secondary School Science Teacher.Fifth Edition. London. Merril Publishing Company.

Tim Redaksi Sinar Grafika. (1999). UndangUndang Otonomi Daerah 1999. Jakarta: Sinar Grafika.

Wahab, A. A. (2002). Guru Profesional dan PIPS yang Kuat Prasyarat bagi Keberhasilan Implementasi Kurikulum Sekolah Berbasis Kompetensi.Makalah.Disampaikan pada Seminar Nasional Sehari IPS, FPIPS IKIP Neheri Singaraja, Tanggal 10 Agustus 2002. 